\title{
FAKTOR PENYEBAB TERJADINYA KEKERASAN DALAM RUMAH TANGGA TERHADAP PEREMPUAN
}

\author{
${ }^{1}$ Rosma Alimi, ${ }^{2}$ Nunung Nurwati \\ 1rosma19001@mail.unpad.ac.id ²nngnurwati@yahoo.com \\ ${ }^{1,2}$ Kesejahteraan Sosial, Fakultas Ilmu Sosial dan Ilmu Politik, Universitas Padjadjaran
}

\begin{abstract}
ABSTRAK
Kekerasan memang tidak memandang gender, namun terlihat sangat jelas dari data yang disajikan bahwa kekerasan terhadap perempuan sangatlah mengkhawatirkan. Konflik yang tidak kian usai dapat menimbulkan Kekerasan Dalam Rumah Tangga (KDRT). Tingkat KDRT yang setiap tahunnya cenderung meningkat menandakan bahwa korban mulai menyadari bahwa tindak KDRT bukanlah sesuatu yang dapat dinormalisasi, sehingga korban memiliki hak untuk memperjuangkan hak hidup aman dan lebih baik. Pernikahan yang seharusnya menjadi sebuah ruang yang nyaman untuk sepasang manusia, justru menjadi ruang paling menakutkan bagi sebagian perempuan. Adapun faktor-faktor terjadinya kekerasan terhadap perempuan dalam rumah tangga khususnya yang dilakukan oleh suami terhadap istri sangatlah beragam. KDRT merupakan sebuah perilaku yang memberikan dampak yang sangat kompleks terhadap perempuan korban KDRT. Tindak kekerasan tersebut menghasilkan dampak psikologis terhadap perempuan korban KDRT. Salah satu upaya penanganan yaitu adanya pemenuhan hak terhadap perempuan korban KDRT. Pemahaman budaya kesetaraan sangat dibutuhkan dalam kehidupan berpasangan, keluarga, maupun masyarakat. Dengan fakta, data, dan aturan dalam Undang-Undang yang sudah ada dan ditetapkan, seharusnya pemerintah dan lembaga-lembaga anti kekerasan terhadap perempuan dapat bergerak lebih luwes lagi untuk membantu dan melindungi perempuan korban kekerasan.
\end{abstract}

\section{Kata Kunci: KDRT, Perempuan, Kekerasan}

\begin{abstract}
Violence is not see gender, but is clearly evident from the data presented above that violence against women is alarming. After the conflict he could cause domestic violence. The domestic violence which annually tended to increase indicates that starting to realize that victims of domestic violence is not something that can be normalized, the victim has a right to safe enforcing their rights and better. Marriage should be a room that is comfortable for a pair of men, have been the most terrifying for some women. As for the causes of domestic violence against women particularly those undertaken by the husband against the wife is very diverse. Behavior that domestic violence is a very complex impact the victims of domestic violence against women. Psychological violence resulted in the impact the victims of domestic violence against women. One of efforts to handle the fulfillment of the rights of the victims of domestic violence against women. Understanding culture equality is needed in the life of in pairs, family, and the community. To the fact, data, and rules in a law that was and set, the government should and institutions anti violence against women can move more flexible again to help and protect women a victim of violence.
\end{abstract}

Key Words: Domestic Violence, Women, Violence 


\section{PENDAHULUAN}

Setiap pasangan suami istri tentunya berharap untuk memiliki kehidupan keluarga yang penuh kasih sayang dan kebahagiaan. Setiap keluarga pada awalnya selalu mendambakan kehidupan rumah tangga yang aman, nyaman, dan membahagiakan (Rochmat 2006). Namun tidak bisa dipungkiri kehidupan berkeluarga memang tidak hanya tentang kasih sayang dan kebahagian. Sepasang suami istri bahkan sebuah keluarga juga dapat menghadirkan konflik yang pelik akibat kesalah pahaman atau ketidak sesuai antara satu sama lain diantara anggota keluarga. Konflik yang tidak kian usai dapat menimbulkan Kekerasan Dalam Rumah Tangga (KDRT).

Perilaku kekerasan merupakan respons terhadap stresor yang dihadapi seseorang yang ditunjukkan dengan perilaku aktual melakukan kekerasan, baik pada diri sendiri, orang lain secara fisik maupun psikologis (Berkowits 2000 in Yosep 2011). Perilaku kekerasan merupakan suatu keadaan dimana seseorang melakukan tindakan yang dapat membahayakan secara fisik, baik pada dirinya sendiri maupun orang lain, disertai dengan amuk dan aduh, gelisah yang tidak terkontrol (Kusumawati and Hartono 2011). Perilaku kekerasan adalah suatu keadaan dimana klien mengalami perilaku yang dapat membahayakan diri sendiri, lingkungan termasuk orang lain dan barang-barang (Maramis and Maramis 2009). Perilaku kekerasan atau suatu tindak kekerasan merupakan ungkapan perasaan dengan melakukan tindakan yang keliru karena hilangnya kontrol diri akibat adanya stresor yang menjadi permasalahan secara fisik maupun psikologis yang mengakibatkan bahaya terhadap diri sendiri, individu lain maupun lingkungan.

Persentase kasus kekerasan yang terdaftar dalam Simfoni Kementerian Perlindungan Perempuan dan Anak menyatakan bahwa hingga pada tahun 2021 terdapat 20,4\% kasus kekerasan terjadi pada laki-laki dan 79,6\% kasus kekerasan terjadi pada perempuan. (Kementerian Perlindungan Perempuan dan Anak 2020). Kekerasan terhadap perempuan di ranah personal terjadi dalam berbagai jenis, seperti kekerasan terhadap istri (KTI), kekerasan dalam pacaran
(KdP), kekerasan terhadap anak perempuan (KTAP), kekerasan yang dilakukan oleh mantan suami (KMS) dan kekerasan mantan pacar (KMP), kekerasan yang terjadi pada pekerja rumah tangga, dan ranah personal lainnya (Komnas Perempuan 2021).

Kekerasan memang tidak memandang gender, namun terlihat sangat jelas dari data yang disajikan di atas bahwa kekerasan terhadap perempuan sangatlah mengkhawatirkan. Selain itu, Kemen PPA juga menyajikan data bahwa Kekerasan Dalam Rumah Tangga (KDRT) merupakan kekerasan dengan tingkat paling tinggi saat ini (Kementrian Perlindungan Perempuan dan Anak 2020). Bentuk KDRT tidak hanya kekerasan secara fisik, namun masih ada bentuk lainnya dan lebih kompleks. Sehingga sangat dibutuhkan Undang-Undang yang dapat melindungi korban KDRT, khususnya terhadap perempuan yang lebih sering menjadi korban KDRT. Tercantum dalam Pasal 5 UndangUndang No. 23 tahun 2004 Tentang PKDRT mengenai setiap kekerasan fisik, kekerasan psikis, kekerasan seksual atau penelantaran rumah tangga. Undang-Undang tersebut bertujuan untuk memberikan perlindungan, penanganan secara khusus, pendampingan oleh pekerja sosial, dan pelayanan bimbingan kerohanian terhadap korban KDRT.

Tujuan Penelitian ini adalah untuk mengetahui bentuk KDRT, faktor penyebab terjadinya KDRT, dampak terhadap psikologis perempuan korban KDRT dan upaya penangan terhadap perempuan korban KDRT. Sedangkan manfaat penelitian ini, hasilnya dapat mengemukakan penyebab terjadinya KDRT terhadap perempuan. Hasil penelitian ini juga dapat dijadikan sebagai bahan pembelajaran mengenai KDRT.

\section{METODE PENELITIAN}

Penelitian ini menggunakan metode pendekatan studi kepustakaan karena mengumpulkan data yang berasal dari buku, jurnal, internet, atau literatur tertulis lainnya sebagai landasan penulisan. Studi pustaka menjadi metode pengumpulan data dengan pencarian informasi melalui buku, koran, dan literatur lain yang bertujuan untuk menyusun teori (Arikunto 2006). Studi pustaka merupakan kajian teoritis, referensi dan studi 
Jurnal Pengabdian dan

Penelitian Kepada Masyarakat

(JPPM)

literatur lain yang berhubungan dengan budaya, nilai, dan norma yang berkembang pada penelitian (Sugiyono 2012).

Tahapan analisis data dalam penelitian ini menggunakan beberapa tahap prosedur. Pertama, peneliti terlebih dahulu menentukan jenis studi kasus yang ingin dilakukan yaitu Faktor Penyebab Terjadinya Kekerasan Dalam Rumah Tangga Terhadap Perempuan. Selanjutnya, peneliti mengumpulkan data dengan menggunakan studi kepustakaan melalui buku, jurnal, disertasi, tesis, skripsi, laporan penelitian, makalah, laporan/kesimpulan seminar, tulisan resmi yang diterbitkan oleh pemerintah atau lembaga-lembaga yang lain, data digital atau internet, dan literatur lainnya. Berikutnya, peneliti melakukan analisis dengan menggunakan data yang telah tersedia sebelumnya. Kemudian, peneliti mendeskripsikan informasi dengan menarik kesimpulan untuk mengambil tindakan. Terakhir, penyajian data kualitatif disajikan dalam bentuk teks naratif, data yang telah diteliti dan dimaknai dalam bentuk kata-kata atau kalimat dalam mendeskripsikan fakta yang ada di lapangan untuk mengambil hasil dan kesimpulan.

\section{HASIL DAN PEMBAHASAN}

Terdapat tiga teori yang mendasari faktor penyebab KDRT. Pertama, teori biologis menyatakan bahwa tidak hanya hewan yang memiliki sifat agresif pada setiap dirinya, tetapi juga manusia sudah memilikinya sejak lahir. Sigmund Freud menyatakan bahwa manusia memiliki keinginan terhadap kematian yang mengarahkannya untuk menikmati tindakan melukai dan membunuh orang lain ataupun dirinya sendiri. Sedangkan Konrad Lorenz menyatakan bahwa sifat agresif dan kekerasan merupakan dua hal sangat berguna untuk bertahan hidup. Kedua, teori frustasiagresi menyatakan bahwa setiap orang yang sedang frustasi cenderung dapat bersifat agresif dengan alasan untuk melampiaskan perasaannya. Ketiga, teori kontrol menyatakan bahwa manusia yang memiliki hubungan tidak memuaskan atau tidak sesuai dapat dengan mudah untuk terpaksa berbuat kekerasan ketika usaha untuk menjalin hubungan dengan manusia lain menghadapi situasi frustasi (Zastrow and Bowker 1984).

\section{Definisi KDRT}

Kekerasan dalam Rumah Tangga adalah setiap perbuatan terhadap seseorang terutama perempuan, yang berakibat timbulnya kesengsaraan atau penderitaan secara fisik, seksual, psikologis, dan/ atau penelantaran rumah tangga termasuk ancaman untuk melakukan perbuatan, pemaksaan, dan perampasan kemerdekaan secara melawan hukum dalam lingkup rumah tangga (Pemerintah Indonesia 2004). Tingkat KDRT yang setiap tahunnya cenderung meningkat menandakan bahwa korban mulai menyadari bahwa tindak KDRT bukanlah sesuatu yang dapat dinormalisasi, sehingga korban memiliki hak untuk memperjuangkan hak hidup aman dan lebih baik. Namun, dengan tingkat KDRT yang cenderung meningkat juga memberikan tanda bahwa sangat dibutuhkannya peninjauan ulang terhadap perlindungan yang telah ada dan dilakukan saat ini agar dapat lebih efisien dalam terhadap perlindungan korban KDRT.

Tabel 1.

Jenis KDRT Tahun 2020

\begin{tabular}{|l|l|}
\hline \multicolumn{1}{|c|}{$\begin{array}{c}\text { Jenis KDRT/ } \\
\text { Relasi Personal }\end{array}$} & \multicolumn{1}{|c|}{$\begin{array}{c}\text { Jumlah } \\
\text { Kasus } \\
\text { KDRT/Relasi } \\
\text { Personal }\end{array}$} \\
\hline Kekerasan Terhadap Istri & $3.221(50 \%)$ \\
\hline Kekerasan Dalam Pacaran & $1.309(20 \%)$ \\
\hline $\begin{array}{l}\text { Kekerasan Terhadap Anak } \\
\text { Perempuan }\end{array}$ & $954(15 \%)$ \\
\hline Kekerasan Mantan Pacar & $401(6 \%)$ \\
\hline Kekerasan Manta Suami & $127(2 \%)$ \\
\hline $\begin{array}{l}\text { Kekerasan Lainnya di Ranah } \\
\text { Personal }\end{array}$ & $457(7 \%)$ \\
\hline Surat Catatan Tamal & \\
\hline
\end{tabular}

Sumber: Catatan Tahunan Komas Perempuan, 2021.

Data di atas merupakan sebuah fakta bahwa banyaknya jenis KDRT/ Relasi Personal terhadap perempuan yang menandakan semakin banyak perempuan yang menjadi korban KDRT. Fokus kali ini yaitu kekerasan terhadap perempuan yang sudah menikah. Pernikahan yang seharusnya menjadi sebuah ruang yang nyaman untuk sepasang manusia, justru menjadi ruang paling 
Jurnal Pengabdian dan

Penelitian Kepada Masyarakat

(JPPM)

e ISSN: $2775-1929$

p ISSN: 2775 - 1910

Vol. 2 No.1

Hal: 20 - 27

April 2021

menakutkan bagi sebagian perempuan. Akan sangat sulit bagi seorang perempuan untuk melaporkan kekerasan yang terjadi kepadanya dengan berbagai alasan, baik alasan secara personal, keluarga, maupun budaya di sekitar lingkungan korban. Data di atas merupakan bentuk sebuah gambaran yang perlu diketahui, karena pada kenyataanya masih banyak perempuan korban kekerasan khususnya seorang istri yang belum tercatat oleh lembagalembaga yang menaungi kasus kekerasan. Maka pemerintah seharusnya dapat memberikan edukasi mengenai kekerasan kepada masyarakat luas agar masyarakat dapat lebih peduli dengan keadaan sekitar dan memahami alur pertolongan untuk korban kekerasan.

Tabel 2.

Jumlah Kasus Kekerasan Terhadap Istri

\begin{tabular}{|c|c|}
\hline $\begin{array}{c}\text { Kasus Kekerasan } \\
\text { Terhadap Istri }\end{array}$ & Jumlah Kasus \\
\hline 2016 & 5.784 \\
\hline 2017 & 5.267 \\
\hline 2018 & 5.114 \\
\hline 2019 & 6.555 \\
\hline 2020 & 3.221 \\
\hline
\end{tabular}

Sumber: Catatan Tahunan Komas Perempuan, 2021.

Menurut data Catahu 2021 KDRT terhadap istri pada tahun 2020 memang menurun secara signifikan jika dibandingkan dengan tahun-tahun sebelumnya. Namun fenomena turunnya tingkat KDRT terhadap perempuan seharusnya tidak membuat masyarakat menjadi lengah, karena pada kenyataannya kekerasan terhadap istri masih menjadi kekerasan di ranah personal dengan tingkat paling tinggi setiap tahunnya. Selain itu, masih banyak kekerasan terhadap perempuan yang perlu dihadapi untuk menciptakan ruang aman bagi semua perempuan di setiap ruang dan waktu.

\section{Bentuk KDRT}

Menurut pasal 5-9 Undang-Undang PKDRT No. 23 Tahun 2004, dinyatakan bahwa bentuk-bentuk KDRT sebagai berikut:

a. Kekerasan fisik, yaitu perbuatan yang mengakibatkan rasa sakit, jatuh sakit atau luka berat. b. Kekerasan psikis, yaitu perbuatan yang mengakibatkan ketakutan, hilangnya rasa percaya diri, hilangnya kemampuan untuk bertindak, rasa tidak berdaya, dan/atau penderitaan psikis berat pada seseorang.

c. Kekerasan seksual, yaitu pemaksaan hubungan seksual yang dilakukan terhadap orang dalam lingkup rumah tangga tersebut dan pemaksaan hubungan seksual terhadap salah seorang dalam lingkup rumah tangganya dengan orang lain untuk tujuan komersial dan/atau tujuan tertentu.

d. Penelantaran rumah tangga, yaitu menelantarkan orang dalam lingkup rumah tangganya, padahal menurut hukum yang berlaku baginya atau karena persetujuan atau perjanjian ia wajib memberikan kehidupan, perawatan, atau pemeliharaan kepada orang tersebut. penelantaran juga berlaku bagi setiap orang yang mengakibatkan ketergantuangan ekonomi dengan cara membatasi dan/atau melarang orang bekerja yang layak di dalam atau di luar rumah sehingga korban berada di bawah kendali orang tersebut (Pemerintah Indonesia 2004).

Tabel 3.

Bentuk KDRT

\begin{tabular}{|l|l|}
\hline Bentuk KDRT & Jumlah Kasus \\
\hline Kekerasan Fisik & 2.025 Kasus \\
\hline Kekerasan Seksual & 1.938 Kasus \\
\hline Kekerasan Psikis & 1.792 Kasus \\
\hline Kekerasan Ekonomi & 680 Kasus \\
\hline $\begin{array}{l}\text { Sumber: Catatan } \\
\text { Perempuan, 2021. Tahunan Komnas }\end{array}$
\end{tabular}

Faktor Penyebab Terjadinya KDRT

Faktor-faktor terjadinya kekerasan terhadap perempuan dalam rumah tangga khususnya yang dilakukan oleh suami terhadap istri yaitu:

a. Adanya hubungan kekuasaan yang tidak seimbang antara suami dan istri. Budaya patriarki membuat laki-laki atau suami berada dalam tingkat kekuasaan yang lebih tinggi daripada perempuan atau istri, sehingga perempuan tidak jarang ketika sudah 
menikah dianggap sebagai milik suaminya. Hal tersebut menimbulkan ketimpangan dalam hubungan karena suami memiliki kuasa lebih terhadap istrinya dibandingkan istrinya sendiri.

b. Ketergantungan ekonomi. Pendidikan dan Budaya patriarki yang sudah menjadi bagian dalam masyarakat memberikan pandangan bahwa seorang istri memang seharusnya bergantung pada suami. Fenomena ini tidak jarang membuat sebagian istri tidak terbiasa mandiri atau berdaya secara ekonomi, sehingga ketika terjadi KDRT membuat istri harus bertahan. Perilaku seperti ini juga membuat suami merasa memiliki kuasa lebih akan ketidak berdayaan istrinya.

c. Kekerasan sebagai alat untuk menyelesaiakan konflik. Kekerasan terhadap istri terjadi biasanya dilatar belakangi oleh ketidak sesuaian harapan dengan kenyataan suami. Kekerasan dilakukan dengan tujuan agar istri dapat memenuhi harapannya tanpa melakukan perlawanan karena ketidak berdayaannya. Fenomena ini juga masih menjadi salah satu dasar budaya dalam masyarakat bahwa jika perempuan atau istri tidak menurut, maka harus diperlakukan secara keras agar ia menjadi penurut.

d. Persaingan. Pada dasarnya manusia hidup memang penuh persaingan dan tidak pernah mau kalah, begitupun dengan sepasang suami dan istri. Persaingan antara suami dan istri terjadi akibat ketidak setaraan antara keduanya untuk saling memenuhi keinginan masing-masing, baik dalam pendidikan, pergaulan, penguasaan ekonomi, keadaan lingkungan kerja dan masyarakat dapat menimbulkan persaingan yang dapat menimbulkan terjadinya KDRT. Budaya juga membuat pandangan bahwa laki-laki tidak boleh kalah atau lebih rendah dari perempuan, sehingga tidak heran jika terjadi kekerasan terhadap perempuan atau istri hanya untuk memenuhi ego laki-laki atau suami.

e. Frustasi. Kekerasan juga dapat terjadi akibat lelahnya psikis yang menimbulkan frustasi diri dan kurangnya kemampuan coping stress suami. Frustasi timbul akibat ketidak sesuaian antara harapan dan kenyataan yang dirasakan oleh suami. Hal ini biasa terjadi pada pasangan yang belum siap kawin, suami belum memiliki pekerjaan dan penghasilan tetap yang mencukupi kebutuhan rumah tangga, dan masih serba terbatas dalam kebebasan. Dalam kasus ini biasanya suami mencari pelarian kepada mabuk-mabukan dan perbuatan negatif lain yang berujung pada pelampiasan berbentuk kekerasan terhadap istrinya, baik secara fisik, seksual, psikis, atau bahkan penelantaran keluarga.

f. Kesempatan yang kurang bagi perempuan dalam proses hukum. Dalam proses sidang pengadilan, sangat minim kesempatan istri untuk mengungkapkan kekerasan yang dialaminya. Hal ini juga terlihat dari minimnya KUHAP membicarakan mengenai hak dan kewajiban istri sebagai korban, karena posisi dia hanya sebagai saksi pelapor atau saksi korban. Hal ini penting karena bisa jadi laporan korban kepada aparat hukum dianggap bukan sebagai tindakan kriminal tapi hanya kesalahpahaman dalam keluarga (Pangemanan 1998).

Menurut Bonaparte (2012), ada beberapa hambatan dalam penangan dan perlindungan korban KDRT, misalnya korban mencabut pengaduan dengan berbagai alasan, misalnya demi keutuhan keluarga atau kondisi psikologis anak, korban secara ekonomi tergantung pada pelaku, korban takut ancaman dari pelaku/ suami, dan adanya campur tangan pihak keluarga atau alasan budaya/adat/norma agama. Kurangnya bukti, yang disebabkan beberapa hal, misalnya menghindari anak sebagai saksi, mengingat kondisi psikologis anak dan dampaknya; menjaga netralitas saksi dalam lingkungan rumah tangga; korban tidak langsung melapor setelah kejadian sehingga terjadi kesulitan ketika melakukan visum; penelantaran ekonomi karena pelaku tidak mempunyai pekerjaan/ penghasilan (Susiana 2020). 
Dalam hal ini terlihat jelas bahwa sangat dibutuhkan pemaham budaya kesetaraan dalam kehidupan berpasangan, keluarga, maupun masyarakat. Pemaham budaya kesetaraan setidaknya dapat membuat khususnya para laki-laki tidak lagi harus bersusah payah memenuhi ekspektasi budaya patriarki yang dimana menempatkan laki-laki harus selalu di atas perempuan. Padahal dengan budaya kesetaran, laki-laki dan perempuan dapat saling menemukan titik kemampuan dalam pemenuhan keinginan sesuai dengan kapasitas diri masing-masing tanpa harus merasa bahwa diri laki-laki rendah ketika perempuan yang justru melakukan pemenuhan kebutuhan tersebut.

\section{Dampak Psikologis Perempuan Korban KDRT}

Setiap perilaku individu dapat menghasilkan dampak bagi diri sendiri, individu lain, bahkan kelompok. KDRT merupakan sebuah perilaku yang memberikan dampak yang sangat kompleks terhadap perempuan korban KDRT. Seperti yang sudah dijelaskan dibagian sebelumnya, bahwa terdapat beberapa bentuk kekerasan, seperti kekerasan fisik, seksual, psikis, dan ekonomi. Tindak kekerasan tersebut menghasilkan dampak psikologis terhadap perempuan korban KDRT, misalnya korban merasa cemas, ketakutan, depresi, selalu waspada, terus terbayang bila melihat kasus yang mirip, sering melamun, murung, mudah menangis, sulit tidur, hingga mimpi buruk. Korban kehilangan rasa percaya diri untuk bertindak karena merasa tidak berdaya, kehilangan minat untuk merawat diri sehingga tidak teraturnya pola hidup yang dijalani, dan kehilangan keberanian dalam berpendapat dan bertindak. Menurunnya tingkat konsentrasi korban, sehingga sering melakukan perbuatan ceroboh. Selalu merasa kebinggungan dan mudah lupa. Korban merasa rendah diri dan tidak yakin dengan kemampuan yang dimilikinya. Korban menjadi pendiam, enggan untuk ngobrol, sering mengurung diri di kamar. Korban sering menyakiti diri sendiri dan melakukan percobaan bunuh diri. Berperilaku berlebihan dan tidak lazim cenderung sulit mengendalikan diri. Agresif, menjadi karakter yang tempramen dan emosi kasar dalam berbicara maupun bertindak. (Maisah and Yenti 2016).
Sebagaimana dikemukakan oleh Jalaluddin, bahwa psikologi secara umum memang mempelajari gejala-gejala kejiwaan manusia yang berkaitan dengan pikiran (cognisi), perasaan (emotion), dan kehendak (conasi). Gejala tersebut secara umum memiliki ciri-ciri yang hampir sama pada diri manusia dewasa, normal dan beradab. Dengan demikian ketiga gejala pokok tersebut dapat diamati melalui sikap dan perilaku manusia. Namun terkadang ada di antara pernyataan dalam aktivitas yang tampak itu merupakan gejala campuran, sehingga paraahli psikologi, yaitu pikiran, perasan, kehendak dan gejala campuran seperti integensi, kelelahanmaupun sugesti (Jalaluddin and Abdullah Idi 2012).

\section{Upaya Penanganan Terhadap Perempuan Korban KDRT}

Salah satu upaya penanganan yaitu adanya pemenuhan hak terhadap perempuan korban KDRT. Undang-Undang Republik Indonesia no. 23 Tahun 2004 merupakan Undang-undang yang telah mengatur pemenuhan hak korban KDRT. Pada Bab IV pasal 10 tentang hak-hak korban terdapat lima hal yaitu:

a. Perlindungan dari pihak keluarga, kepolisian, kejaksaaan, advokat, lembaga sosial, atau pihak lainnya baik sementara maupun berdasarkan penetapan perintah perlindungan dari pengadilan;

b. Pelayanan kesehatan sesuai dengan kebutuhan medis;

c. Penanganan secara khusus berkaitan dengan kerahsiaan korban;

d. Pendampingan oleh pekerja sosial dan bantuan hukum pada setiap tingkat proses pemeriksaan sesuai dengan ketentuan peraturan perundangundangan; dan

e. Pelayanan bimbingan rohani.

Selain adanya pasal yang mengatur mengenai pemenuhan hak korban KDRT, pemerintah dan masyarakat juga memiliki kewajiban untuk memberikan perlindungan terhadap korban KDRT dan sudah ditetapkan pada Bab dan Pasal selanjutnya. Pada Bab V tentang kewajiban pemerintah dan masyarakat pada pasal 13 dan 14 sebagai berikut:

Pasal 13 berbunyi untuk penyelenggaraan pelayanan terhadap korban, 
pemerintah dan pemerintah daerah sesuai dengan fungsi dan tugasnya masing-masing dapat melakukan upaya:
a. Penyediaan ruang pelayanan
b. khusus di kantor kepolisian;
c. Penyediaan aparat, tenaga kesehatan, pekerja sosial, dan pembimbing rohani;
d. Pembuatan dan pengembangan sistem dan mekanisme kerja sama program pelayanan yang melibatkan pihak yang mudah di akses oleh korban; dan
e. Memberikan perlindungan bagi pendamping, saksi, kelurga, dan teman korban.

Pasal 14 berbunyi menyelenggarakan upaya sebagaimana dimaksud dalam Pasal 13, pemerintah dan pemerintah daerah sesuai dengan fungsi dan tugas masing-masing, dapat melakukan kerja sama dengan masyarakat atau lembaga sosial lainnya (Pemerintah Indonesia 2004).

\section{SIMPULAN DAN SARAN}

Berdasarkan pemaparan yang telah disampaikan, maka dapat ditarik kesimpulan bahwa KDRT terhadap perempuan merupakan perilaku yang tidak sesuai dengan norma. Semua bentuk kekerasan memang tidak memandang gender sebagai korban, namun dari data kasus yang ada hampir $80 \%$ korban kekerasan merupakan seorang perempuan. Karena fokus penelitian kali ini KDRT terhadap perempuan dan datapun menunjukan bahwa Kekerasan Terhadap Istri (KTI) masih menunjukan tingkat paling atas jika dibandingkan dengan jenis kekerasan terhadap perempuan lainnya. KDRT pada dasarnya terjadi akibat adanya dorongan secara internal dan eksternal. Secara internal dorongan hadir dari diri pelaku karena adanya stresor yang dihadapi dengan perilaku agresif akibat kurangnya kemampuan coping stress. Sedangkan jika dilihat secara eksternal, maka dorongan budaya patriarki yang diyakini oleh masyarakat luas yang menjadi akar penyebab masalah kekerasan dan faktor penyebab kekerasan antara suami dan istri terjadi.

Dengan fakta, data, dan aturan dalam Undang-Undang yang sudah ada dan ditetapkan, seharusnya pemerintah dan lembaga-lembaga anti kekerasan terhadap perempuan dapat bergerak lebih luwes lagi untuk membantu dan melindungi perempuan korban kekerasan. Pemerintah dan aparatur negara seharusnya mulai mempercayai korban yang sudah berani melaporkan diri, bukan mempertanyakannya bahwa seakan-akan hal tersebut tidak dapat dipercaya. Pendidikan terhadap masyarakat mengenai kekerasan, perlindungan terhadap korban, dan budaya kesetaran harus lebih diupayakan agar semua lapisan masyarakat dapat ikut andil dalam mengurangi tingkat kekerasan terhadap perempuan.

\section{DAFTAR PUSTAKA}

Arikunto. 2006. Prosedur Penelitian Suatu Pendekatan Praktek. Jakarta. PT. Rineka Cipta.

Jalaluddin, Haji, and Haji Abdullah Idi. 2012. Filsafat Pendidikan: Manusia, Filsafat, Dan Pendidikan. Jakarta: Rajagrafindo Persada.

Kementrian Perlindungan Perempuan dan Anak. 2020. "Data Sistem Informasi Online Perlindungan Perempuan Dan Anak (SIMFONI PPA) Kemen PPPA." https://kekerasan.kemenpppa.go.id/ringk asan.

Komnas Perempuan. 2021. "Perempuan Dalam Himpitan Pandemi: Lonjakan Kekerasan Seksual, Kekerasan Siber, Perkawinan Anak Dan Keterbatasan Penanganan Di Tengah Covid-19." CATAHU 2021: Catatan Tahunan Kekerasan terhadap Perempuan 2020.

Kusumawati, Farida, and Yudi Hartono. 2011. Buku Ajar Keperawatan Jiwa. Jakarta: Salemba Medika.

Maisah, and Yenti. 2016. "Dampak Psikologis Korban Kekerasan Dalam Rumah Tangga Di Kota Jambi." Esensia 17(2): 265-77.

Maramis, Willy F, and Albert A Maramis. 2009. Catatan Ilmu Kedokteran Jiwa Edisi 2. Surabaya: Airlangga University Press.

Pangemanan, Diana Ribka. 1998. "Tindak Kekerasan Terhadap Perempuan Dalam Keluarga." Universitas Indonesia.

Pemerintah Indonesia. 2004. "Undang Undang Nomor 23 Tahun 2004 Tentang 


\begin{tabular}{|c|c|c|c|c|}
\hline $\begin{array}{c}\text { Jurnal Pengabdian dan } \\
\text { Penelitian Kepada Masyarakat } \\
\text { (JPPM) }\end{array}$ & $\begin{array}{c}\text { e ISSN: 2775 - 1929 } \\
\text { p ISSN: 2775 - 1910 }\end{array}$ & Vol. 2 No.1 & Hal: 20 - 27 & April 2021 \\
\hline
\end{tabular}

Kekerasan Dalam Rumah Tangga." Lembaran RI Tahun 2004 No. UU. https://www.dpr.go.id/.

Rochmat, Wahab. 2006. "Kekerasan Dalam Rumah Tangga: Perspektif Psikologis Dan Edukatif." Unisia 61(3): 247-56.

Sugiyono. 2012. Metode Penelitian Kuantitatif Kualititatif Dan $R \& B$. Bandung: Alfabeta.
Susiana, Sali. 2020. "Kekerasan Dalam Rumah Tangga Pada Masa Pandemi Covid-19." Info Singkat 12(24): 13-18.

Yosep, Iyus. 2011. Keperawatan Jiwa (Edisi Revisi). Bandung: Refika Aditama.

Zastrow, Charles, and Lee Bowker. 1984. Social Problems: Issues and Solutions. Chicago: Nelson-Hall. 